\title{
LEGAL BASIS OF ENVIRONMENT IMPACT EVALUATION
}

\author{
T. M. KONDRATIUK, assistant \\ of Department of Agricultural, Land and Environmental Law \\ named after Academician V.Z. Yanchuk, \\ National University of Life and Environmental Sciences of Ukraine \\ E-mail: Lawyert@ukr.net \\ R. R. ROMAN, student of land management faculty, \\ National University of Life and Environmental Sciences of Ukraine \\ E-mail:org2227@gmail.com
}

Summary. In this scientific article investigated basic legal regulation points of impact on environment evaluation, when it conducts economical activity. We made the analyzing of national law on the impact environment evaluation by the European standards.

Keywords: evaluation, environmental impact, planning, citizen discussion, environment protection

\section{Introduction.}

The social relations in ecology consist of solving legal tasks: decreasing of anthropological factors negative influence, formation the guarantees of law legal realization on creating favorable environment. When we conduct the economical activity, we, firstly, must anticipate environmental damage, provide environmental protection, environmental guard, engrain rational resource usage and recycling by using organization and legal mechanisms.

\section{Analysis of recent researches and publications.}

The main native scientists that investigates tasks of environment legal guard: A.P. Hetman, V.I. Andreetseva, V.M. Yermolenko, M.V. Krasnov, I.I. Karakash, A.Y. Godanyuk, Y.S.
Shemshuchenko etc. Today, we need the independent analysis for legal estimation impact on economical activity environment that includes actuality and modernity for Ukraine in this task.

The purpose of the work is analyzing laws of special legislation, that, determines legal bases on making environmental impact evaluation. This work will help to use legal norms for all law activity subjects.

\section{Results.}

The environment law guard is not the individual country problem. It hasn't got any national borders and it gets globalization character [1, p. 398]. The main orienteer of getting quality social relations reglamentacion, including environment guard, is European Union law. The basis of this law consist notion 
of getting stable evolution of Europe and the whole Earth.

In the 18 December 2017 was accepted the Ukrainian law «About environmental impact evaluation» that was approved in 23 May 2017 by № 2059-VIII (nextly named like Law). The law was accepted with the European methods of economical activity environment evaluation [2]. Because of that, the Ukrainian law «About ecological expertise» from the 9 February 1995 by № 45/95-BP had been demolished. The law was accepted by the plan of association agreement between Ukraine and European Union. Then the directive 2011/92/ EU from 13 December 2011 was accepted in national law in the environment case. This directive was called «About the evaluation of country and private project impact on environment» (nextly Directive). The law has implemented the European model of environment impact evaluation like the integrated and conventional system. This model has been existed 25 years in European Union. The law basis of environmental impact evaluation has determined in: Convention «Environmental impact evaluation by transboundary context» [3] and Convention «About access to the information, the citizen activity in decision-making and access to justice aspect in the environment tasks».

Environment impact evaluation is working by: the natural environment law rules that includes the place condition characteristic, where will be planed activity, ecological risks and prognoses, region social-economic perspectives, capacity and types of cumulative impacts (direct and indirect) on the environment with consisting of existent objects impact, planed activity objects and with objects that will have planed activity or this activities is questioned (p. 2) [2]. Economical activity, that must be evaluate, includes constructing, reconstructing, , technical re-equipment, expansion, re-engineering, liquidation (disassembly) of objects and other impact on natural environment. There are two categories of types economical activities that must be evaluate. The first type is activity that must be considered about grounds for carrying out an assessment of transboundary environmental impacts because of Ukrainian international obligations (part. 5 p. 3).In this case, the conclusion about environment impact evaluation issuing by the Ministry of Environmental Protection. The country defense, consequences emergency liquidation, ATO consequences liquidation planning activity mustn't be environment impact evaluate. The ATO consequences liquidation is ruled by «Criteria for determining the planned activity, that mustn't be environment impact evaluate and criteria for defining extensions and changes in activities and objects, that mustn't be evaluate», approved by the resolution of the Ukrainian Ministers Cabinet in 13 December 2017 by № 989 [6].

The term «Impact» means any environment planned activities consequences. It includes human life and wellness safety consequences, flora, fauna, biodiversity, soil, air, water, climate, landscape, nature territories and objects, historical scapes and other objects or summary of factors, also culture or social-economical conditions consequences that existed like change results of these factors. «Evaluation» - it is procedure, which protect environment from damage, create ecological protection, create environment guard, rationalized nature resource usage, in decision-making process about economical activity conduction that could have a big impact on environment, including country, citizen and private interests. 
This procedure includes: 1) creating the environment impact evaluation report by economic subject; 2) making citizen discussion; 3) Making the information analysis by state agency about environmental impact evaluation report, about any add information, which afford economical subject, and also about information that has been taken from citizens in the citizen discussion, in time of transboundary impact evaluation, other information; 4) Creating the report about environment impact evaluation, that considers results of analysis, by special agency; 5) Consideration the conclusion about environment impact evaluation in case of proceeding the planning activity (p. 2).

The law now includes a new permission document - environment impact conclusion, which supersedes ecological country expertise conclusion. The positivity is that the economical subject must create environment impact evaluation before making the decision on conducting planning activity; it means that evaluation creates before the project realization start. In contradistinction to the ecological country expertise, when it was allowed to create it after taking the permissions to build object.

Like in European standards (paragraph. 6 Directive) [8], one of the main environment impact evaluation principles is publicity and public opinion, which become real because of citizen discussion. Interested community, which gets damage or could be risked to take damage becomes a part of evaluation procedure. Message about planning activity, advert about beginning of evaluation report citizen discussion, information about environment impact conclusion and decision about planning activity (with concrete agency, number and date of acceptance) published by creating post on official web-sites of regional, city Kiev state administration (p. 4) [2]. When planned activity, could have transboundary impact, or could have impact on 2 and more regions (AR Crimea), or client is region, Kiev or Sevastopol country city administrations, considers the exclusion zone and the zone of unconditional (mandatory) resettlement territory, which has been nuclear because of Chornobyl accident, and/or decision about acceptance that adopted by the Cabinet of Ministers of Ukraine, pay by foreign credits with country guarantee - information published on ecological ministry site that includes date of official publication. The citizen discussion conduction in environment evaluation process accepted by Ukrainian M.C. decree from 13 December 2017 [4]. Because of this decree the independent subject has been appeared, it is the citizen discussion organizer. It could be person or entity -businessman, which has the experience in environment guard more than 2 years and he has technical and human resources that are needed for citizen discussion holding in specific region or regions that regulated by ecological ministry or regional, Kiev or Sevastopol country city administration; once a year on concourse by the contract including Ukrainian Law requirements «About public procurement». But, the law consist the ability for central or territorial agencies about making citizen discussions independent, without «organizer», in this case agency does all functions that must citizen discussion organizer done by rules. Whereas, inputting new citizen discussion subjects-organizer task is, in our mind, controversial: firstly - it is addition wasting of money that based on economical subject, secondly - it is added time, which need in the 
buying procedure. The evaluation procedure because of big amount of steps and terms of their completing is very durable and it is includes twice more time than ecological expertise (from 4 till 6 months). Report about citizen discussion added and includes, while the environmental impact evaluation preconclusion work is doing.

Information about environment impact that includes quantitative and qualitative indicators of pollutions, physical and biological impact factors, usage of natural resources and garbage handling, is opened and access couldn't be limited [5]. In case of Law the environment impact evaluation Unified register introduced, which procedure determined with the Ukrainian M.C. decree from the 13 December 2017 № 1026 [5]. The register information has got an open access; you could find it at Ecological ministry site.

The evaluation end result means that economical subject gets environment impact evaluation conclusion, which is a compulsory permission document that determined by law and it must be done. This conclusion could be a reason to refuse the decision giving about planning activity. The results and conclusion in 5 years from taking the decision about planning activity could be used for getting other permissive character documents. Conclusion validity is 5 years, if there are no taken decisions, the conclusion expires.

The Law consist postprojecting monitoring (p. 13). It is implemented if it is necessary to do it in environmental impact evaluation conclusion, and it used to detect any differences and deviations in projected exposure levels and it used for doing more effective measures to prevent and reduce pollution.

If the conclusion isn't fulfilled, the economical subjects will stop their activity. This decision decided not by specifically agencies (regional, Kiev or Sevastopol country administrations), it decided only by judge. Reasons of temporary activity forbidden placed in the 16 paragraph in Law, they are: violation of emergency impact evaluation law in case of economical activity, object exploitation, other impacts on nature and landscape, almost, extraction of minerals, use of man-made mineral deposits, environmental conditions, foreseen in the conclusion, etc. Reasons for stopping business activity or their parts or equipment could be planning activity, that must be evaluated, without doing evaluation and it could be planning activity or systematic violations that couldn't be eliminated for technical, economic or other reasons [2].

\section{Discussion.}

Ukrainian Law «About environment impact evaluation» is a legal instrument that existed to prevent negative ecological consequences to environment, that more modern and closer to European standards. The main rules of this Law are publicity and open accessing of environment impact evaluation procedure: citizen discussion settled, environment impact evaluation unified register has been opened. The Law has got concrete procedure and terms of documents granted, which completed without official eye contact, it completed by mail posting. However, in order to understand the effectiveness of the Law in work, there must pass some time.

\section{References}

1. Getman, A.P., Anisimova, A.V., Sokolova, A.K. (2014). Environmental Law Ukraine: textbook for students, lawyer specialists, higher teachers, establishments. Kharkiv: Law, 432. 
2. About assessment of environmental impact: Law of Ukraine dated May 23, 2017, № 2059-VIII. Official Bulletin of Ukraine. (2017), 50, 5.

3. About the assessment of the environmental impact in a transboundary context: the Convention ratified by the Law of Ukraine of March 19, 1999 № 534-XIV. Available at: http://zakon.rada.gov.ua/laws/ show/995_272.

4. Procedure for conducting public hearings in the process of environmental impact assessment: Decree of the Cabinet of Ministers of Ukraine dated December 13, 2017, № 989. Official Bulletin of Ukraine (2018), 2, 200.

5. Procedure for the transfer of documentation to provide an opinion on the environmental impact assessment and financing of the environmental impact assessment and the Procedure for maintaining the Unified Register for Environmental Impact Assessment: Decree of the Cabinet of Ministers of Ukraine dated December 13, 2017, № 1026.
Official Bulletin of Ukraine (2018), 2, 212.

6. On approval of criteria for the definition of planned activities that are not subject to environmental impact assessment and criteria for defining extensions and changes in activities and objects that are not subject to an environmental impact assessment: Decree of the Cabinet of Ministers of Ukraine dated December 13, 2017, № 989. Official Bulletin of Ukraine (2018), 3, 23.

7. Convention on Access to Information, Public Participation in Decision-making and Access to Justice in Environmental Matters: The Convention, ratified by the Law of Ukraine of July 6, 1999 № 832XIV. Available at: zakon.rada.gov.ua/laws/ show/994_015.

8. Directive 2011/92 / EU of 13 December 2011 on the assessment of the impact of certain public and private projects on the environment. Available at: http://enref. org/.../dyrektyva-2011-92-es-pro-otsinku -vplyvu-okre.

T. М. Кондратюк, Р. Р. Роман (2019). Правові засади оцінки впливу

на довкілля. Право. Людина. Довкілля, 10(1): 97-101, https://doi.org/10.31548/ law2019.01.013.

Анотація. Устаттідосліджено основні моменти правового регулювання оцінки впливу на довкілля при провадженні господарської діяльності. Проведено аналіз національного законодавства у частині оцінки впливу на довкілля відповідно до європейських стандартів.

Ключові слова: оцінка, вплив на довкілля, планова діяльність, громадські обговорення, охорона довкілля 